\title{
The Efficacy of Ezetimibe Combined with Simvastatin in Patients with Coronary Heart Disease and Its Effect on Serum Retinol Binding Protein 4, Thioredoxin Interaction Protein and Visceral Adipose Tissue Serine Protease Inhibitor
}

\author{
XIANG DONG YOU*, HUA ZHANG, YUANYUAN LIU AND HUIBIN QI
}

Department of Cardiology, The Fourth Central Hospital of Baoding City, Hebei Province 072350, China

You et al.: Efficacy of Ezetimibe Combined with Simvastatin in Coronary Heart Disease Patients

\begin{abstract}
To observe the efficacy of ezetimibe combined with simvastatin with coronary heart disease patients and its effect on retinol binding protein 4, thioredoxin interaction protein and visceral adipose tissue serine protease inhibitor. 120 patients with coronary heart disease admitted in our hospital from May 2019 to May 2020 were divided into the control group and the observation group. Changes in serum retinol binding protein 4 , thioredoxin interaction protein and visceral adipose tissue serine protease inhibitor and blood lipids were recorded. Changes in the Seattle angina scale in the observation group, 18 patients were effective and the total effective rate were $93.33 \% ; 27$ patients showed effect in the control group, 21 patients were effective and the total effective rate was $80.00 \%$; the total effective rate in the observation group was higher than that in the control group, with statistical significance $(p<0.05)$. Compared with those before treatment, visceral adipose tissue serine protease inhibitor and high density lipoprotein cholesterol increased, retinol binding protein 4 , thioredoxin interaction protein, triglyceride, total cholesterol and low density lipoprotein cholesterol decreased in the two groups and visceral adipose tissue serine protease inhibitor and high density lipoprotein cholesterol were higher and retinol binding protein 4, thioredoxin interaction protein, triglyceride, total cholesterol and low density lipoprotein cholesterol were lower in the observation group than those in the control group after 3 mo of treatment $(p<0.05)$. The ezetimibe combined with simvastatin can regulate blood lipid, decrease the expression of retinol binding protein 4 , thioredoxin interaction protein and visceral adipose tissue serine protease inhibitor in serum and improve the onset of angina pectoris in patients with coronary heart disease.
\end{abstract}

Key words: Ezetimibe, simvastatin, coronary heart disease, retinol binding protein 4, thioredoxin interaction protein, visceral adipose tissue serine protease inhibitor

Coronary Heart Disease (CHD) refers to coronary atherosclerosis caused by lipid deposition on the arterial wall, which narrows or blocks the vascular lumen for a long time and eventually leads to myocardial hypoxia, ischemia and even necrosis ${ }^{[1,2]}$. Studies have shown ${ }^{[3]}$ that abnormal lipid metabolism is an independent risk factor for the onset of CHD. Visceral Adipose Tissue Serine Protease Inhibitor (Vaspin) is an endothelial cell protective factor, which can protect endothelial cells and improve the inflammatory state of the body by inducing the process of Nitric Oxide (NO) biosynthesis. Therefore, the serum level of Vaspin can be used as an important basis for patients with vascular endothelial damage in clinical practice ${ }^{[4,5]}$.

Thioredoxin Interaction Protein (TXNIP) mediates the oxidative stress reaction of patients and has a positive correlation with the degree of coronary artery stenosis ${ }^{[6]}$. Retinol Binding Protein 4 (RBP4) is mainly secreted by liver and fat cells and is a kind of fatsoluble vitamin transporter molecule, which is highly

*Address for correspondence

E-mail: youxiangdong2021@163.com 
expressed in diseases such as obesity, hypertension and coronary heart disease ${ }^{[7,8]}$. Statins have a clear role in regulating the lipids of coronary heart disease, in which simvastatin is considered the first-line drug for clinical intervention of cardiovascular disease ${ }^{[9]}$.

However, some patients who take statins to lower their lipids will experience a "statin escape" phenomenon. It has been reported in the literature ${ }^{[10,11]}$ that ezetimibe reduces approximately half of cholesterol absorption in the intestine, particularly significantly reduces Low Density Lipoprotein Cholesterol (LDL-C) absorption and it is believed that ezetimibe combined with simvastatin has a complementary role in inhibiting cholesterol absorption. There are no studies on the effects of these two drugs on serum RBP4, TXNIP and Vaspin in patients with CHD and this study is based on this.

\section{MATERIALS AND METHODS}

\section{General data:}

120 patients with CHD admitted in our hospital from May 2019 to May 2020 were divided into groups according to their therapeutic regimen. 60 patients in the control group were treated with simvastatin, including 33 males and 27 females; aged 18-70 y old, with mean age of $(53.06 \pm 11.18) \mathrm{y}$ old; course of disease is $2-19$ $y$, with mean course of disease of $(10.14 \pm 3.69)$ y; 24 patients with stable angina pectoris and 36 patients with unstable angina pectoris.

In the observation group, 60 patients were treated with ezetimibe combined with simvastatin, including 31 males and 29 females; aged 21-70 y old, with a mean age of (54.51 \pm 11.02$)$ y old; course of disease is 2-19 $y$, with a mean course of disease $(10.06 \pm 3.71)$ y; 27 patients with stable angina pectoris and 33 patients with unstable angina pectoris.

Inclusion criteria includes CHD meeting the criteria in Internal Medicine (2008) ${ }^{[12]}$; Aged $\geq 18 \mathrm{y}$ old and $\leq 70 \mathrm{y}$ old; Diagnosed by clinical symptoms, medical history and coronary angiography; Complete medical records. Exclusion criteria includes Allergic constitution; Patients with acute coronary syndrome or acute myocardial infarction; Patients with mental disorder or cognitive disorder; Patients taking other lipid modifying drugs; Patients with other severe somatic diseases; Patients who were pregnant or lactating women. There was no significant difference in general data between the two groups $(\mathrm{p}>0.05)$.

\section{Methods:}

Both groups were treated routinely, maintained on a low cholesterol diet and treated symptomatically. The control group was given Simvastatin (produced by Beijing NHU Winsunny Pharmaceutical Co., Ltd., approval No.: H20050948, specification: $40 \mathrm{mg}$ ), 20 $\mathrm{mg} /$ time, once a day (qd) for $3 \mathrm{mo}$. The observation group additionally received ezetimibe (manufactured by MSD Pharma (Singapore) Pte. Ltd, approval No.: H20130837, specification: $10 \mathrm{mg}$ ), $10 \mathrm{mg} /$ time, qd for 3 mo. Monitor liver and kidney function carefully during administration.

Before and after 3 mo of treatment, $3 \mathrm{ml}$ of fasting venous blood was collected centrifuged at $2500 \mathrm{r} / \mathrm{min}$ for $5 \mathrm{~min}$ and the supernatant was taken to obtain the serum to be tested. Serum Total Cholesterol (TC), Triglyceride (TG), LDL-C and High-Density Lipoprotein Cholesterol (HDL-C) levels were measured by RLMax automatic biochemical analyzer produced by Siemens, Germany. Serum TXNIP and Vaspin levels were determined by Enzyme-Linked Immunosorbent Assay (ELISA) using a NDM-9602G automatic enzyme labeling analyzer (Beijing Perlong New Technology Co., Ltd.) and a reagent produced by US Research and Development (R\&D) company. Make quantitative analysis according to the color reaction intensity, conduct detection at wavelength of $450 \mathrm{~nm}$, draw standard curve according to the concentration and absorbance of standards and calculate the sample level to be tested according to the standard curve. Immunoturbidimetry is adopted for serum RBP4 and the kit is purchased from Shanghai Gensource Medical Appliances Co., Ltd.

\section{Observation indicators and detection methods:}

Efficacy criteria includes Significantly effective: Symptoms and signs disappeared after treatment and the frequency of angina pectoris decreased by $\geq 90 \%$; Effective: Symptoms and signs improved after treatment, $\leq 50 \%$ frequency of angina pectoris decreased by $<90 \%$; Ineffective: The above criteria were not $\operatorname{met}^{[13]}$.

The Seattle Angina Questionnaire (SAQ) score ${ }^{[14]}$ was positively associated with quality of life, including physical limitation, stable angina, angina attacks, satisfaction degree and disease awareness degree. Safety: Observe the adverse reactions during medication.

\section{Statistical methods:}

The data were treated with Statistical Package for the Social Sciences (SPSS) 19.0, the measurement indicators were described with $(\overline{\mathrm{x}} \pm \mathrm{s}), \mathrm{t}$ test was used for 
comparison and the counting data were compared with $\chi^{2}$ test, $\mathrm{p}<0.05$, which showed a statistical significance.

\section{RESULTS AND DISCUSSION}

The total effective rate in the observation group was higher than that in the control group and there was statistical significance $(\mathrm{p}<0.05)$ (Table 1$)$.

Compared with that before treatment, Vaspin was increased and RBP4 and TXNIP were decreased in the two groups. Vaspin was higher in the observation group than in the control group, RBP4 and TXNIP were lower in the observation group than in the control group after treatment $(\mathrm{p}<0.05)$ (Table 2).

Compared with that before treatment, HDL-C increased and TG, TC and LDL-C decreased in the two groups and the above indicators in the observation group were better than those in the control group after treatment $(\mathrm{p}<0.05)$ (Table 3).

Compared with that before treatment, the scores of physical limitation, stable angina pectoris, angina attack, satisfaction degree and disease cognition degree

TABLE 1: COMPARISON OF EFFICACY BETWEEN THE TWO GROUPS [n (\%)]

\begin{tabular}{lccccc}
\hline Group & Number of cases & Effect & Effective & Invalid & Total effectiveness \\
\hline Control group & 60 & $27(45.00)$ & $21(35.00)$ & $12(20.00)$ & $48(80.00)$ \\
Observation group & 60 & $38(63.33)$ & $18(30.00)$ & $4(6.67)$ & $56(93.33)$ \\
$\chi^{2}$ & & & & 4.615 \\
$\mathrm{p}$ & & & & 0.032 \\
\hline
\end{tabular}

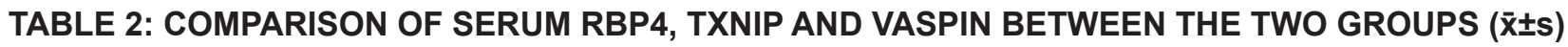

\begin{tabular}{|c|c|c|c|c|c|c|c|}
\hline \multirow[b]{2}{*}{ Group } & \multirow{2}{*}{$\begin{array}{c}\text { Number of } \\
\text { cases }\end{array}$} & \multicolumn{2}{|c|}{ RBP4 ( $\mu \mathrm{g} / \mathrm{l})$} & \multicolumn{2}{|c|}{ TXNIP (ng/ml) } & \multicolumn{2}{|c|}{ Vaspin $(\mu g / l)$} \\
\hline & & $\begin{array}{c}\text { Before } \\
\text { treatment }\end{array}$ & $\begin{array}{c}\text { After } \\
\text { treatment }\end{array}$ & $\begin{array}{c}\text { Before } \\
\text { treatment }\end{array}$ & $\begin{array}{c}\text { After } \\
\text { treatment }\end{array}$ & $\begin{array}{c}\text { Before } \\
\text { treatment }\end{array}$ & $\begin{array}{c}\text { After } \\
\text { treatment }\end{array}$ \\
\hline Control group & 60 & $71.85 \pm 12.06$ & $60.03 \pm 8.25^{*}$ & $302.56 \pm 48.69$ & $264.25 \pm 31.05^{*}$ & $0.92 \pm 0.23$ & $1.43 \pm 0.29^{*}$ \\
\hline $\begin{array}{l}\text { Observation } \\
\text { group }\end{array}$ & 60 & $69.31 \pm 11.71$ & $52.26 \pm 6.79^{*}$ & $294.85 \pm 51.74$ & $228.63 \pm 27.41^{*}$ & $0.95 \pm 0.22$ & $1.91 \pm 0.32^{*}$ \\
\hline $\mathrm{t}$ & & 1.170 & 5.633 & 0.841 & 6.662 & 0.730 & 8.609 \\
\hline$p$ & & 0.244 & 0.000 & 0.402 & 0.000 & 0.467 & 0.000 \\
\hline
\end{tabular}

Note: Compared with this group before treatment, ${ }^{*} \mathrm{p}<0.05$

TABLE 3: COMPARISON OF BLOOD LIPIDS BETWEEN THE TWO GROUPS ( $\overline{\mathrm{x}} \pm \mathbf{s}, \mathrm{mmol} / \mathrm{l})$

\begin{tabular}{|c|c|c|c|c|c|c|c|c|c|}
\hline \multirow[b]{2}{*}{ Group } & \multirow[b]{2}{*}{$\begin{array}{l}\text { Number } \\
\text { of cases }\end{array}$} & \multicolumn{2}{|c|}{ TG } & \multicolumn{2}{|c|}{$\mathrm{TC}$} & \multicolumn{2}{|c|}{ LDL-C } & \multicolumn{2}{|c|}{ HDL-C } \\
\hline & & $\begin{array}{c}\text { Before } \\
\text { treatment }\end{array}$ & $\begin{array}{c}\text { After } \\
\text { treatment }\end{array}$ & $\begin{array}{c}\text { Before } \\
\text { treatment }\end{array}$ & $\begin{array}{c}\text { After } \\
\text { treatment }\end{array}$ & $\begin{array}{c}\text { Before } \\
\text { treatment }\end{array}$ & $\begin{array}{c}\text { After } \\
\text { treatment }\end{array}$ & $\begin{array}{c}\text { Before } \\
\text { treatment }\end{array}$ & $\begin{array}{c}\text { After } \\
\text { treatment }\end{array}$ \\
\hline $\begin{array}{l}\text { Control } \\
\text { group }\end{array}$ & 60 & $7.12 \pm 1.03$ & $5.32 \pm 0.67^{*}$ & $3.26 \pm 0.85$ & $2.42 \pm 0.51^{*}$ & $4.85 \pm 0.59$ & $3.51 \pm 0.42^{*}$ & $1.05 \pm 0.33$ & $1.56 \pm 0.37^{*}$ \\
\hline $\begin{array}{l}\text { Observation } \\
\text { group }\end{array}$ & 60 & $7.03 \pm 1.15$ & $4.25 \pm 0.52^{*}$ & $3.31 \pm 0.78$ & $1.81 \pm 0.37^{*}$ & $4.92 \pm 0.66$ & $2.45 \pm 0.39^{*}$ & $1.01 \pm 0.41$ & $1.95 \pm 0.42^{*}$ \\
\hline $\mathrm{t}$ & & 0.452 & 9.772 & 0.336 & 7.499 & 0.612 & 14.326 & 0.589 & 5.397 \\
\hline $\mathrm{p}$ & & 0.652 & 0.000 & 0.738 & 0.000 & 0.541 & 0.000 & 0.557 & 0.000 \\
\hline
\end{tabular}

Note: Compared with this group before treatment, ${ }^{*} \mathrm{p}<0.05$

TABLE 4: COMPARISON OF SAQ SCORES BETWEEN THE TWO GROUPS ( $\bar{x} \pm \mathbf{s}$, points)

\begin{tabular}{lccccc}
\hline Dimensions & Time & $\begin{array}{c}\text { Control group } \\
(\mathrm{n}=60)\end{array}$ & $\begin{array}{c}\text { Observation group } \\
(\mathbf{n}=60)\end{array}$ & $\mathrm{t}$ & $\mathrm{p}$ \\
\hline \multirow{2}{*}{ Physical limitations } & Before treatment & $54.23 \pm 10.14$ & $51.85 \pm 11.65$ & 1.194 & 0.235 \\
& After treatment & $64.04 \pm 7.85^{*}$ & $78.14 \pm 10.58^{*}$ & 8.290 & 0.000 \\
Stable state of & Before treatment & $45.02 \pm 9.85$ & $46.11 \pm 10.74$ & 0.579 & 0.563 \\
angina & After treatment & $60.03 \pm 12.45^{*}$ & $79.35 \pm 8.05^{*}$ & 10.094 & 0.000
\end{tabular}




\begin{tabular}{lccccc}
\multirow{2}{*}{ Angina attack } & Before treatment & $52.36 \pm 12.63$ & $55.02 \pm 17.14$ & 0.968 & 0.335 \\
& After treatment & $59.68 \pm 15.44^{*}$ & $72.36 \pm 11.45^{*}$ & 5.110 & 0.000 \\
Satisfactory & Before treatment & $53.63 \pm 13.02$ & $51.84 \pm 12.56$ & 0.766 & 0.445 \\
treatment & After treatment & $62.67 \pm 10.05^{*}$ & $73.14 \pm 10.81^{*}$ & 5.495 & 0.000 \\
\multirow{2}{*}{ Disease awareness } & Before treatment & $45.69 \pm 15.04$ & $44.26 \pm 14.13$ & 0.537 & 0.592 \\
& After treatment & $57.98 \pm 11.47^{*}$ & $69.69 \pm 12.03^{*}$ & 5.457 & 0.000 \\
\hline
\end{tabular}

Note: Compared with this group before treatment, ${ }^{*} p<0.05$

increased in the two groups and the scores of SAQ in the observation group were higher than those in the control group after treatment $(\mathrm{p}<0.05)$ (Table 4). No serious adverse reactions occurred during treatment.

CHD is characterized by coronary atherosclerosis and changes in cholesterol metabolism parameters can be used as a key factor in the assessment of CHD and therefore lipid-modifying therapy in patients with CHD must be noted ${ }^{[15]}$. Studies have shown that the effects of statin lipid-lowering drugs on cholesterol lowering have great benefits in CHD and the protective effects of statin lipid-lowering drugs are far beyond the range of lipid lowering drugs themselves, which can prevent plaque formation and development, prevent thrombosis formation and promote ischemic myocardium.

Improvements in angiocarpy and endothelial cell function, antioxidant and anti-inflammation are important functions. Anti-inflammatory effects are important for plaque stability. Simvastatin, an important agent for lipid lowering in patients with CHD, has been shown to significantly enhance the activity of cell surface LDL-C receptors, accelerate the elimination and breakdown of LDL-C and reduce LDL-C levels ${ }^{[16]}$.

However, some patients treated with simvastatin had low compliance and if they did not adhere to a lowfat diet or other factors, the patients' lipid metabolism would be disorganized. Therefore, simvastatin needs to be combined with other lipid lowering drugs.

The results of this study showed that compared with those before treatment, HDL-C increased and TG, TC and LDL-C decreased in both groups. After treatment, HDL-C in the observation group was higher than that in the control group, and TG, TC and LDL-C were lower than that in the control group.

These results were associated with the inhibition of endogenous cholesterol synthesis by simvastatin and the inhibition of exogenous absorption of cholesterol by ezetimibe to achieve a highly potent lipid lowering effect. During the lipid lowering process of simvastatin, the synthesis of cholesterol in the liver is limited and absorption feedback from cholesterol in the gut is increased, which is unbalanced.

The action of ezetimibe on the cholesterol transporter Niemann-Pick C1-Like 1 (NPC1L1) affects cholesterol transport in the small intestine. It can significantly reduce the absorption of cholesterol, accelerate the metabolism of cholesterol and produce complementary effects and the combination of both has higher safety.

In this study, the total effective rate in the observation group was significantly higher than that in the control group, with statistical significance. The combination of simvastatin and ezetimibe may enhance the lipid lowering effect, improve lipid compliance and have a high safety profile.

The results of this study showed that compared with those before treatment, scores of the physical limitation, stable angina pectoris, angina attack, satisfaction degree and disease awareness degree of the two groups increased.

The SAQ scores of the observation group were higher than those of the control group after treatment. Compared with those before treatment, the Vaspin, RBP4 and TXNIP of the two groups decreased and the Vaspin, RBP4 and TXNIP of the observation group were higher than those of the control group after treatment. Endothelial injury caused by an inflammatory response to local blood vessels in CHD patients exceeds the patients' ability of self-repair and is of positive significance in the diagnosis of disease severity.

After lipid-lowering therapy, vascular endothelial function was improved and angina attacks were relieved in both groups, with a greater benefit for patients receiving combination therapy. This also suggests that ezetimibe not only has lipid lowering effects, but also may have protective effects on vascular endothelial cells and myocardium and in addition, it may improve endothelial function and reduce cardiomyocytes apoptosis, thereby controlling the atherosclerotic process in patients with CHD. 
Vaspin is one of the highly expressed adipocytokines in visceral fat, whose levels are inversely related to the risk of atherosclerosis, hypertension and stroke, and their levels can also be used to reflect the degree of lipid lowering effect ${ }^{[17]}$.

Ezetimibe is excreted primarily in the feces, is not metabolized by the cytochrome P450 isoenzymes and rarely interacts with other drugs ${ }^{[18]}$. Ezetimibe combined with simvastatin has significant lipid lowering effect and can also reduce the inflammatory response in human body and improve endothelial function, playing a positive role in the treatment of CHD.

This study shows that the addition of ezetimibe can effectively improve the level of Vaspin and reduce the inflammatory response in human body.

This is an important mechanism of the combination regimen. Based on this study, ezetimibe has multiple effects such as reduction in myocardial oxygen consumption, reduction in myocardial damage, anticoagulation and anti-hypoxia.

In conjunction with this study, ezetimibe combined with simvastatin can be used in addition to CHD prevention to significantly reduce serum RBP4 levels. The combination can also prevent red blood cells from adhering to the vascular wall and improve the viscoelasticity of hemorheology. It can also inactivate thrombin, inhibit platelet aggregation, reduce blood clots, decrease blood lipid and improve the level of TXNIP.

Therefore, ezetimibe combined with simvastatin can achieve significant lipid-lowering effect. In recent years ${ }^{[19]}$, some scholars have suggested that ezetimibe not only has good lipid-lowering effect, but also can reverse the development of atherosclerosis and plays an important role in the treatment of CHD.

Previous studies ${ }^{[20]}$ also confirmed the lipid-modifying effect of ezetimibe combined with simvastatin in patients with CHD. In addition, in this study, ezetimibe combined with simvastatin lipid-lowering therapy was found to play an important role in lipid metabolism and angina attacks in patients with CHD. Moreover, it could significantly increase the expression of RBP4, TXNIP and Vaspin in serum, and this study protocol could provide a new idea for the treatment of CHD.

In conclusion, the ezetimibe combined with simvastatin can regulate blood lipid, decrease the expression of
RBP4, TXNIP and Vaspin in serum and improve the onset of angina pectoris in patients with coronary heart disease.

\section{Conflict of interests:}

The authors declared no conflicts of interest.

\section{REFERENCES}

1. Hagström E, Norlund F, Stebbins A, Armstrong PW, Chiswell K, Granger CB, et al. Psychosocial stress and major cardiovascular events in patients with stable coronary heart disease. J Intern Med 2018;283(1):83-92.

2. Mihai VC, Dana ZC, Loredana P, Mădălina M, Mircea P, Mekereș $\mathrm{F}$, et al. Cross-sectional study on a population of diabetes mellitus newly diagnosed patients. Relative risk of coronary heart disease (chd) morbidity using ukpds risk engine. Internal Med 2018;15(1):7-15.

3. Avadhani R, Fowler K, Barbato C, Thomas S, Wong W, Paul C, et al. Glycemia and cognitive function in metabolic syndrome and coronary heart disease. Am J Med 2015;128(1):46-55.

4. Kastl SP, Katsaros KM, Krychtiuk KA, Jägersberger G, Kaun $\mathrm{C}$, Huber $\mathrm{K}$, et al. The adipokine vaspin is associated with decreased coronary in-stent restenosis in vivo and inhibits migration of human coronary smooth muscle cells in vitro. PloS one 2020;15(5):e0232483.

5. Suliga E, Kozieł D, Cieśla E, Rębak D, Wawszczak M, Adamus-Białek W, et al. Associations between vaspin rs2236242 gene polymorphism, walking time and the risk of metabolic syndrome. Balkan J Med Genet 2019;22(1):41-8.

6. Liu Y, Dai C, Lei Y, Wu W, Liu W. Inhibition of EZH2 attenuates coronary heart disease by interacting with microRNA-22 to regulate the TXNIP/nuclear factor- $\mathrm{kB}$ pathway. Exp Physiol 2020;105(12):2038-50.

7. Yang M, Weng H, Pei Q, Jing F, Yi Q. The relationship between retinol-binding protein 4 and markers of inflammation and thrombogenesis in children with kawasaki disease. Mediat Inflamm 2021;2021(4):1-7.

8. Kwanbunjan K, Panprathip P, Phosat C, Chumpathat N, Wechjakwen N, Puduang S, et al. Association of retinol binding protein 4 and transthyretin with triglyceride levels and insulin resistance in rural thais with high type 2 diabetes risk. BMC Endocr Disord 2018;18(1):1-7.

9. Cozma MA, Gaman MA, Dobrica EC, Gaman AM, Diaconu CC. Statin therapy for dyslipidemia and coronary heart disease in patients with type 2 diabetes mellitus. J Hypertens 2019;37(1):e250-1.

10. Doherty DJ, Pottle A, Malietzis G, Hakim N, Barbir M, Crane JS. Vascular access in lipoprotein apheresis: a retrospective analysis from the UK's largest lipoprotein apheresis centre. J Vasc Access 2018;19(1):52-7.

11. Durrington PN, Bhatnagar D, Mackness MI, Morgan J, Julier $\mathrm{K}$, Khan MA, et al. An omega-3 polyunsaturated fatty acid concentrate administered for one year decreased triglycerides in simvastatin treated patients with coronary heart disease and persisting hypertriglyceridaemia. Heart 2001;85(5):544-8.

12. Zaiying L, Nanshan Z. Internal medicine. 7th ed. People's Health Publishing House; 2008.

13. Littmann K, Ahmed O, Gustafsson U, Pramfalk C, Öörni K, Larsson L, et al. Simvastatin and ezetimibe reduce plasma lipoprotein binding to human arterial proteoglycans in gallstone diseased patients. Atherosclerosis 2018;275:e234. 
14. Ya-Wen LU, Ying-Chao ZH, Zhang L, Ping LI, Jie YA, XiaoDong WE. Ilexgenin A enhances the effects of simvastatin on non-alcoholic fatty liver disease without changes in simvastatin pharmacokinetics. Chin J Nat Med 2018;16(6):436-45.

15. Renzhi J, Xiaohong Z, Jing J. Clinical study of ezetimibe tablets combined with simvastatin tablets in the treatment of atherosclerosis with hypercholesterolemia. Chin J Clin Pharmacol 2018;34(18):2131-3.

16. Xianghui H, Yinshi C, Songling W. Effect of ezetimibe combined with atorvastatin on blood lipid and cholinesterase in patients with CHD. Southwest Nat Defense Med 2018;28(5):445-7.

17. Akcilar R, Yümün G, Bayat Z, Donbaloğlu O, Gür Ö, Gürkan S, et al. Association of vaspin rs2236242 gene variants and circulating serum vaspin concentrations with coronary artery disease in a Turkish population. J Cell Physiol 2021;236(5):3734-9.

18. Zeng M, Guang H, Wei YN. Systematic review of ezetimibe combined with statins and double dose statins in the treatment of coronary heart disease. Chin J Evid Based Cardiovasc Med 2019;11(12):28-33.
19. de Lillo A, de Angelis F, di Girolamo M, Luigetti M, Frusconi $\mathrm{S}$, Manfellotto D, et al. Phenome-wide association study of TTR and RBP4 genes in 361,194 individuals reveals novel insights in the genetics of hereditary and wildtype transthyretin amyloidoses. Hum Genet 2019;138(11):1331-40.

20. Xing XZ, Ping JY, Yu FC. Effect of Atorvastatin Combined with ezetimibe on lipid metabolism and inflammatory response in patients with coronary heart disease. Chin J Med Clin 2019;019(004):590-2.

This is an open access article distributed under the terms of the Creative Commons Attribution-NonCommercial-ShareAlike 3.0 License, which allows others to remix, tweak, and build upon the work non-commercially, as long as the author is credited and the new creations are licensed under the identical terms

This article was originally published in a special issue, "Novel Therapeutic Approaches in Biomedicine and Pharmaceutical Sciences"

Indian J Pharm Sci 2021:83(6)Spl issue "1-6" 